\title{
Chapter 29 \\ Fertilization of Brown Algae: Flagellar Function in Phototaxis and Chemotaxis
}

\author{
Gang Fu, Nana Kinoshita, Chikako Nagasato, and Taizo Motomura
}

\begin{abstract}
Sexual reproduction of brown algae includes isogamy, anisogamy, and oogamy. The mechanisms of fertilization events remain largely unknown despite the diverse reproduction patterns. It is thought that the flagella of brown algal reproduction cells play crucial roles in not only cellular motility but also signal transduction in the aquatic habitat. Flagella of brown algae are composed of $9+2$ axonemes and several appendage structures, such as mastigonemes and a paraflagellar body, which have close associations with flagellar function. We observed flagellar activities during recognition and fusion of male and female gametes. We also investigated flagellar proteins involved in phototaxis of brown algal motile cells.
\end{abstract}

Keywords Brown algae $\bullet$ Chemotaxis $\bullet$ Fertilization $\bullet$ Flagella $\bullet$ Phototaxis

\subsection{Flagellar Structure of Brown Algal Swarmers}

Stramenopiles, including heterokonts, comprise an independent group of eukaryotes and are phylogenetically distinct from red and green algae, land plants, and animals (Baldauf 2003). One of the characteristic features of this group is that they have heterogeneous flagella, one of which is decorated with mastigonemes, tripartite fine hairs (van den Hoek et al. 1995). Brown algae, such as Saccharina, Undaria, and Sargassum, are a group of heterokonts and the only group in heterokonts having a complex multicellular organization.

In the life cycle of many brown algae, sporophyte and gametophyte generations exist independently, and sexual reproduction (male and female gametes, or sperm

G. Fu・N. Kinoshita • C. Nagasato • T. Motomura $(\bowtie)$

Muroran Marine Station, Field Science Center for Northern Biosphere,

Hokkaido University, Muroran 051-0013, Japan

e-mail: motomura@fsc.hokudai.ac.jp 


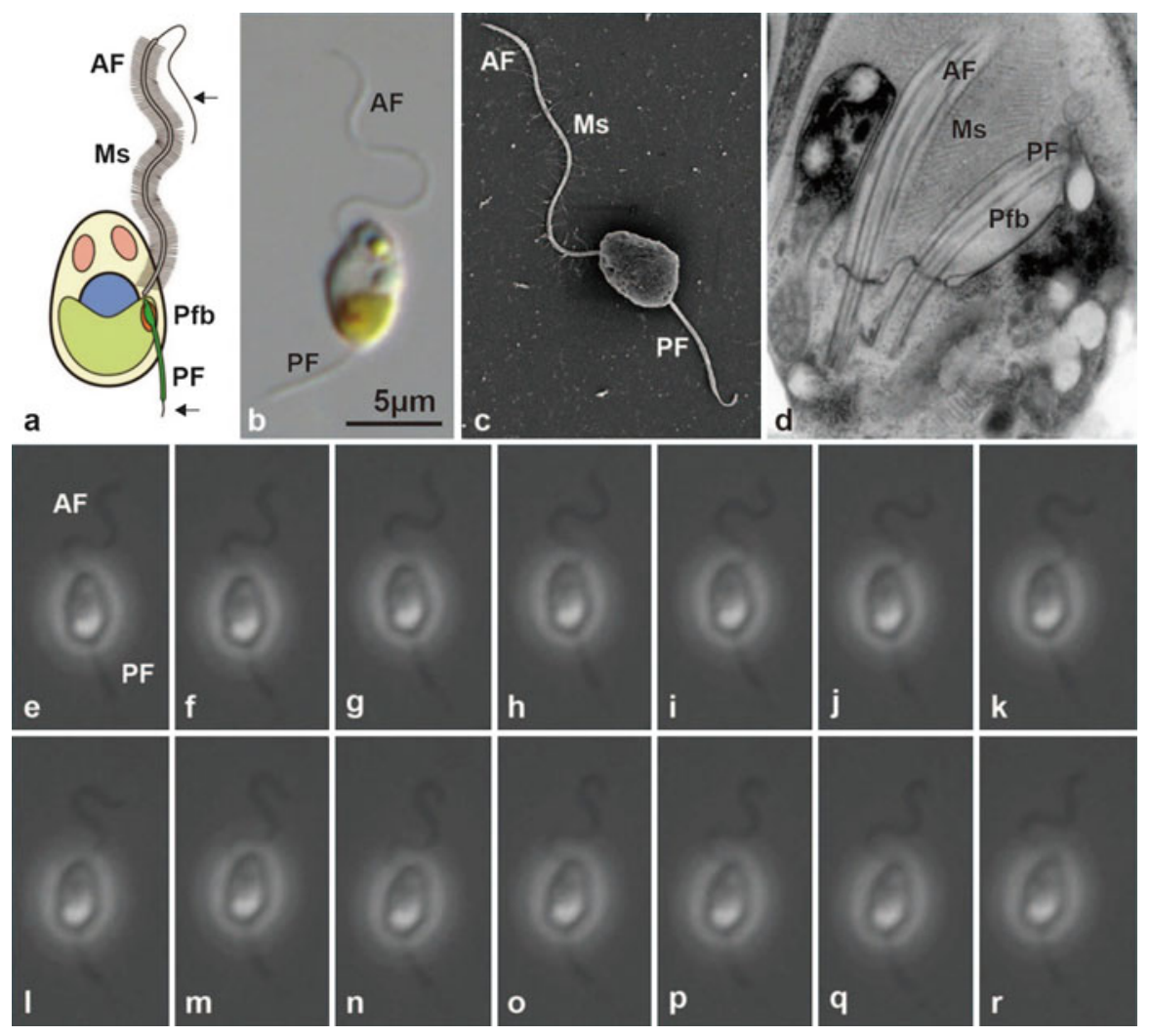

Fig. 29.1 Two heterogeneous flagella of brown algal motile cells. (a) Schematic representation of a motile cell. AF anterior flagellum, Ms mastigonemes, PF posterior flagellum, Pfb paraflagellar body. Arrows show the acronema, tip of the AF, and PF. (b) DIC image of a male gamete of Scytosiphon lomentaria. (c) SEM image of a male gamete of S. lomentaria. Note that mastigonemes are only on the AF. (d) TEM image of the AF and PF of Ectocarpus siliculosus. Note that $\mathrm{Ms}$ is on the AF and Pfb is on the PF. (e-r) High-speed video images (600 frame/s) of free swimming of a $S$. lomentaria male gamete

and egg) and asexual reproduction (zoospore or tetraspore after meiosis) connect the two generations. Swarmers, namely flagellated motile cells (gametes, sperm, and zoospores), have two heterogeneous flagella (Fig. 29.1a-d), a long anterior flagellum (AF) decorated with mastigonemes and a short posterior flagellum (PF) with a basal swollen part called the paraflagellar body, which is composed of crystallized materials and electron-dense materials (Green et al. 1989; Andersen 2004; Fu et al. 2012). The acronema, which is composed of two central microtubules of axonemes, makes the tip of each flagellum. The AF and PF are laterally inserted into the cell body in two opposite directions corresponding to the swimming orientation ( $\mathrm{O}$ ' Kelly 1989). Swimming force of motile cells of brown algae is produced by the AF, not the PF (Fig. 29.1e-r), because motile sperm of the brown alga Dictyota only have an 
$\mathrm{AF}$ (Manton 1959), and it is thought that mastigonemes on the AF would be related to tractive force (Jahn et al. 1964). It has remained unclear how mastigonemes regularly attach only to the AF during flagellar elongation (Fu et al. 2012). The PF of brown algal motile cells functions as steering against signals of light (phototaxis) and chemicals (chemotaxis) (Geller and Müller 1981; Matsunaga et al. 2010).

\subsection{Phototaxis of Brown Algae and a Putative Photoreceptor Protein}

Phototaxis is widespread among motile cells of the major eukaryotic lineages, and a similar mechanism by which phototactic reorientation is complemented is shared despite the great diversity of cell types. When considering fertilization of algae living in an aquatic environment, several processes, including phototaxis, chemotaxis, and recognition, would be critical. Swarmers including gametes and zoospores of algae show a strong response to direction of light from the sun. For example, male and female gametes of the green alga Monostroma angicava, which have two equallength flagella, swim toward the seawater surface after liberation from gametangia, showing positive phototaxis (Togashi et al. 1999). On the other hand, just after fertilization, motile zygotes having four flagella derived from male and female gametes show negative phototaxis and swim toward the bottom of the sea. The change of phototaxis before and after fertilization is necessary for continuous support of successful fertilization, because accumulation of unfertilized male and female gametes at the surface of the sea ensures easy fusion of both gametes. Zygotes settle on boulders on the bottom and develop into the next generation by negative phototaxis (Togashi et al. 1999; Togashi and Cox 2004). In the case of brown algae, for example, isogamous brown algae Scyotosiphon lomentaria, Colpomenia bullosa, and Ectocarpus siliculosus, freshly liberated male and female gametes show strong negative phototaxis, and female gametes settle on the substratum sooner than do male gametes and secrete a sexual pheromone that attracts male gametes. Therefore, in the case of algal fertilization in an aquatic environment, phototaxis reaction is important for dense accumulation of gametes.

In phototaxis reaction of motile cells, a specific photoreceptor senses the light source of restricted wavelength and transduces the signals to downstream molecular modules, which will eventually alter the flagellar beating activity with changing the swimming direction (Jekely 2009). However, different organisms have evolved exclusive strategies in response to light stimuli, for example, employing diverse photoreceptors and the corresponding downstream signaling. In the green alga Chlamydomonas reinhardtii, two light-gated cation-channel proteins, channelrhodopsin-1 (ChR1) and ChR2, were identified as photoreceptors regulating phototaxis through depolarizing photoelectric currents (Sineshchekov et al. 2002; Berthold et al. 2008). Similar to other types of rhodopsins, both proteins are 7-TM membrane proteins and bind retinal as a chromophore. An immunofluorescence assay indicated that ChR1 was localized near the eyespot, which is part of the chloroplast 
(Suzuki et al. 2003). In the unicellular flagellate Euglena gracilis, photoactivated adenylyl cyclase (PAC), a flavoprotein, was shown to be the blue light receptor, which binds flavin adenine dinucleotide (FAD) as a chromophore and localizes to the paraflagellar body (Iseki et al. 2002; Ntefidou et al. 2003).

As another independent eukaryotic group, it has been well known that the PF of swarmers of brown algae has the capability to emit green autofluorescence when excited with blue light. Based on the results of spectral analysis, the substance that caused the green autofluorescence was identified as flavin (Müller et al. 1987; Kawai 1988). Flavin in the PF is widely distributed among chlorophyll $c$-containing algal species having an eyespot or paraflagellar body (Kawai and Inouye 1989; Kawai 1992). Close associations between the autofluorescence substance and presence of an eyespot or paraflagellar body, as well as results of spectral action studies on phototaxis of brown algal swarmers (Kawai et al. 1990, 1991), have suggested that the blue light receptor is a flavoprotein and is likely localized in the PF. However, the photoreceptor protein involved in phototaxis of brown algae has not yet been identified, although a fluorescent flagellar protein homologous to Old Yellow enzyme was found in isolated flagella of S. lomentaria (Fujita et al. 2005), which seems to play roles in general redox reactions rather than light-sensing activities.

In our recent flagellar proteomics studies based on the whole-genome sequence of the model brown alga E. siliculosus (Cock et al. 2010), a putative blue-light receptor protein was found in the PF of brown algal swarmers and might have a close relationship to phototaxis. Flagella were isolated from swarmers of several brown algal species, including $C$. bullosa and $S$. lomentaria, by vortexing in flagellar isolation buffer (30 mM HEPES, $5 \mathrm{mM} \mathrm{MgSO}_{4}, 5 \mathrm{mM}$ EGTA, $25 \mathrm{mM} \mathrm{KCl}, 1 \mathrm{M}$ Sorbitol, pH 7.0). Flagellar proteins were further digested by trypsin and subjected to LC-MS/MS analysis, which yielded about 600 proteins of brown algal flagella. Among PF-specific proteins that were identified by proteomics analysis, an RGS/ LOV domain-containing protein was found to be a potential photoreceptor. This protein contained 1,522 amino-acid residues and the predicted molecular weight was $168 \mathrm{kDa}$. In contrast to known photoreceptors, the protein has a unique domain architecture of two RGS (regulator of G-protein signaling) domains and four LOV (light, oxygen, and voltage sensing) domains. It is well known that the LOV domain is a ubiquitous molecular module capable of binding FMN (flavin mononucleotide) as a chromophore in diverse photoreceptors (Crosson et al. 2003; Losi and Gärtner 2012; Suetsugu and Wada 2013). The RGS domain has a key activity in accelerating GTP hydrolysis by the G $\alpha$ subunit; therefore, it is likely that heterotrimeric G proteins may be involved in the downstream signaling of blue-light sensing, which eventually modifies the beating pattern of the PF of swarmers.

Although the interactions between inner- and interproteins during phototaxis are far from understood, an antibody against the RGS/LOV domain-containing protein revealed that this protein is widely distributed in brown algal species. An immunofluorescence assay confirmed that this protein is localized throughout the PF with a stronger intensity at the paraflagellar body, corresponding to the distribution of green autofluorescence when observed under blue light. In addition, immunoelectron microscopy analysis revealed that the subcellular localization of this protein is in the compartment between the flagellar membrane and axoneme. 


\subsection{Chemotaxis of Brown Algae}

Regarding sexual pheromones in brown algae, since the first discovery of the pheromone "ectocarpen" in E. siliculosus by the German phycologist Dieter G. Müller (Müller 1967, 1968; Müller et al. 1971), eleven sexual pheromones, including lamoxirene, fucoserraten, and hormosirene, have been reported (Maier and Müller 1986; Boland 1995). These brown algal pheromones are volatile, lipophilic, and fragrant and have a low molecular mass with unsaturated $C_{8}$ and $C_{11}$ hydrocarbons with biogenetically related structures. Male gametes actively surround the sexual pheromone that female gametes secrete soon after their settlement on the substratum (Fig. 29.2). Motile female gametes never gather around a settled female one. Therefore, it is clear that the pheromone receptor must naturally exist in the male gamete, not in the female one. In the case of isogamous brown algae, such as E. siliculosus and S. lomentaria, male gametes freely swim in a straight or slightly curved track with maximum velocity in seawater without a pheromone (Fig. 29.1e-r), whereas the PF of male gametes has occasional beats and strong lateral bias with the signal of a pheromone (Fig. 29.2h-k) and, as a result, male gametes swim in a characteristic U-turn (Maier and Müller 1986). Those authors reported chemo-thigmo-klinokinesis, which means that the pheromone has two effects for attracting male gametes around settled female gametes: (1) reducing male gamete velocity by a thigmotactic response and (2) increasing beating frequency of the PF of male gametes in proportion to the pheromone concentration. Unfortunately, the pheromone receptor in male gametes has not yet been identified.

A male gamete attracted to a female gamete by the sexual pheromone shows a characteristic behavior in brown algal fertilization, first making contact with the surface of the female gamete by using the tip of the long AF (Fig. 29.2a-f) (Müller 1966), followed by fusion of both bodies. Therefore, initial recognition and contact between male and female gametes is carried out by using the AF of the male gamete. As already mentioned, the AF of gametes and zoospores of brown algae characteristically bears mastigonemes, which may be involved in the contact between male and female gametes. High-speed video and high-resolution scanning electron microscopy (SEM) reveal the the fusion process of both gametes (Fig. 29.2g-k).

\subsection{Cytoplasmic Inheritance of Organelles}

Finally, we briefly introduce the cytoplasmic inheritance of mitochondria, chloroplasts, and centrioles during zygote development of brown algae. Three types of sexual reproduction - isogamy, anisogamy, and oogamy — can be observed in brown algae, similar to green algae. Cytoplasmic inheritance of mitochondria, chloroplasts, and centrioles is restrictively regulated in each pattern of sexual reproduction (Motomura et al. 2010). In oogamy, mitochondria and chloroplasts of sperm are selectively digested in the lysosome after fertilization (Motomura 1990). In the case of isogamy, chloroplasts are biparentally inherited, whereas mitochondria 


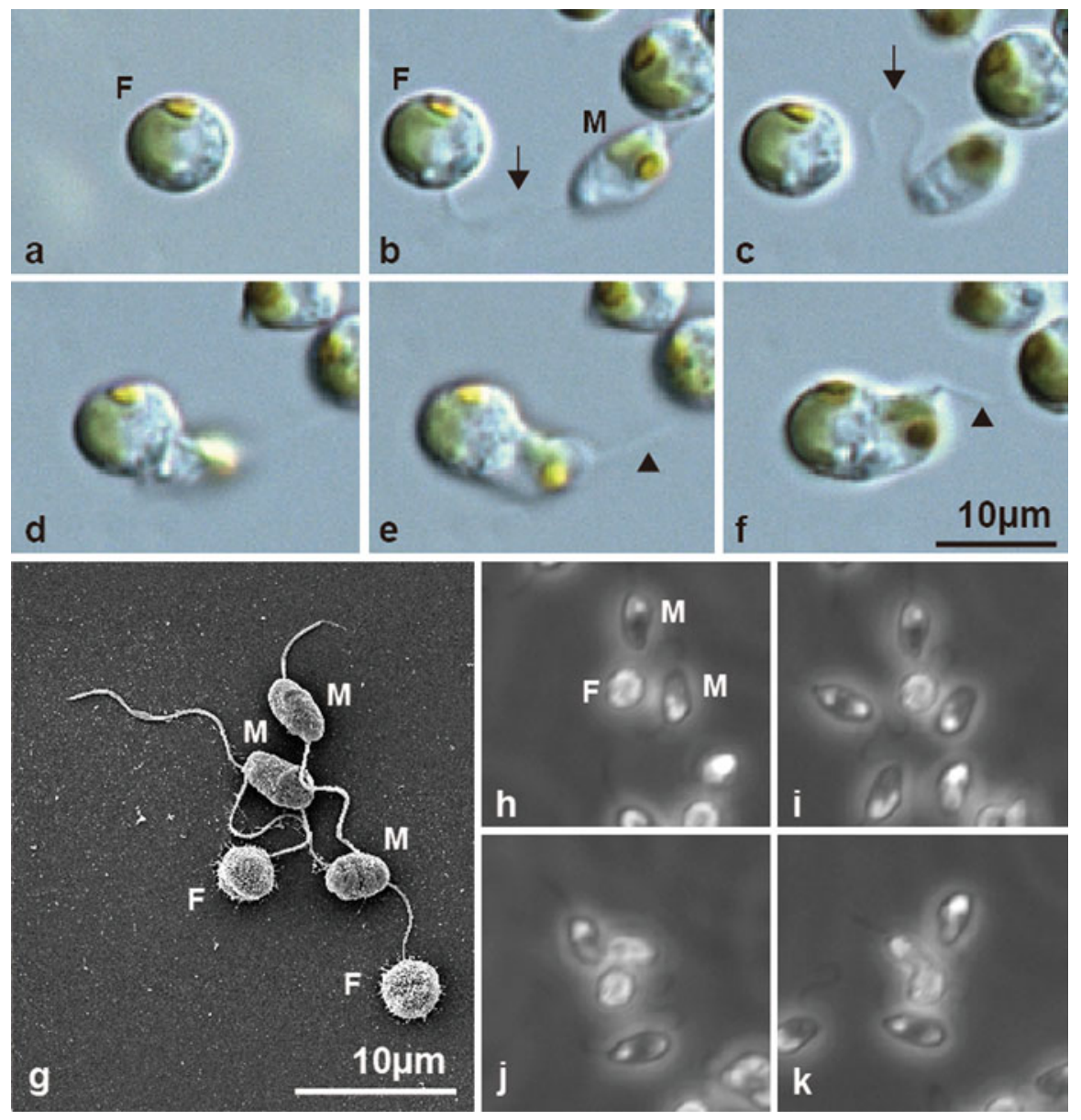

Fig. 29.2 Isogamous fertilization of Scytosiphon lomentaria. (a-f) Process of fertilization between male $(M)$ and female $(F)$ gametes. Female gametes settle on the substratum and then release a pheromone, by which male gametes are attracted. The AF of the male gamete (arrow in b, c) attaches to the cell surface of the female gamete with the flagellar tip. Cell fusion starts, and then the PF (arrowheads in $\mathbf{e , f}$ ) of the male gamete is withdrawn. The zygote becomes a spherical shape within a few minutes. (g) SEM image. Three male gametes gather around two female gametes. (h-k) High-speed video images. Note that the PF of male gamete bends

(or mitochondrial DNA) derived from the female gamete only remain during zygote development (Nagasato and Motomura 2002; Peters et al. 2004; Kato et al. 2006; Kimura et al. 2010). Similar to the paternal inheritance of centrioles in animal fertilization (Schatten 1994), centrioles in zygotes are definitely derived from the male gamete regardless of the sexual reproduction pattern (Nagasato 2005). In isogamous $S$. lomentaria, degeneration of the maternal centrioles was found to start $1 \mathrm{~h}$ after fertilization with degradation of triplet MTs from the distal end, and in a 2-h-old zygote, there was no trace of the maternal centrioles ultrastructurally (Nagasato and Motomura 2004). 


\subsection{Perspectives}

The flagellar structure is the most important character for defining the stramenopile (Heterokontae) in the eukaryote groups. Brown algal swarmers have a long AF bearing fine hairs, mastigonemes, and a short PF having the basal swelling, the parabasal body. With these morphological differences, their behaviors in gamete swimming are also characteristic. During the fertilization process, these heterogeneous flagella play crucial roles in phototaxis, chemotaxis, and gamete recognition. Our proteomics analysis on flagella of the brown algae identified first about 600 flagellar proteins, and AF-specific and PF-specific proteins were found. A candidate protein of the new blue-light receptor, RGS/LOV protein, working in phototaxis of gametes, could be also detected in PF-specific proteins. These molecular approaches will expand a new insight for understanding the function of flagella of male and female gametes of the brown algae during fertilization, including the pheromone receptor that may exist in flagella of male gametes and the molecular nature of the flagellar tip of male gametes for the first attachment to the surface of female gametes.

Acknowledgments We thank Drs. Kazuo Inaba and Kogiku Shiba, Shimoda Marine Research Center, University of Tsukuba, for kindly teaching us to operate the high-speed video camera. Dr. Tatyana A. Klochkova, Kamchatka State Technical University, kindly provided photographs for Fig. 29.2a-f. This study was supported by a Grant-in-Aid for Scientific Research on Innovative Areas from the Ministry of Education, Culture, Sports, Science and Technology.

Open Access: This article is distributed under the terms of the Creative Commons Attribution Noncommercial License which permits any noncommercial use, distribution, and reproduction in any medium, provided the original author(s) and source are credited.

\section{References}

Andersen RA (2004) Biology and systematics of heterokont and haptophyte algae. Am J Bot 91:1508-1522

Baldauf SL (2003) The deep roots of eukaryotes. Science 300:1703-1706

Berthold P, Tsunoda SP, Ernst OP, Mages W, Gradmann D, Hegemann P (2008) Channel rhodopsin-1 initiates phototaxis and photophobic responses in Chlamydomonas by immediate lightinduced depolarization. Plant Cell 20:1665-1677

Boland W (1995) The chemistry of gamete attraction: Chemical structures, biosynthesis, and (a)biotic degradation of algal pheromones. Proc Natl Acad Sci USA 92:37-43

Cock MJ, Sterck L, Rouzé P, Scornet D, Allen AE, Amoutzias G, Anthouard V, Artiguenave F, Aury JM, Badger JH, Beszteri B, Billiau K, Bonnet E, Bothwell JHF, Bowler C, Boyen C, Brownlee C, Carrano CJ, Charrier B, Cho GY, Coelho SM, Collén J, Corre E, Silva CD, Delage L, Delaroque N, Dittami SM, Doulbeau S, Elias M, Farnham G, Gachon CMM, Gschloessl B, Heesch S, Jabbari K, Jubin C, Kawai H, Kimura K, Kloareg B, Küpper FC, Lang D, Le Bail A, Leblanc C, Lerouge P, Lohr M, Lopez PJ, Martens C, Maumus F, Michel G, Miranda-Saavedra D, Morales J, Moreau H, Motomura T, Nagasato C, Napoli CA, Nelson DR, Nyvall-Collén P, Peters AF, Pommier C, Potin P, Poulain J, Quesneville H, Read B, Rensing SA, Ritter A, Rousvoal S, Samanta M, Samson G, Schroeder DC, Ségurens B, Strittmatter M, Tonon T, Tregear J, Valentin L, von Dassow P, Yamagishi T, Van de Peer Y, Wincker P (2010) The 
Ectocarpus genome and the independent evolution of multicellularity in the brown algae. Nature (Lond) 465:617-621

Crosson S, Rajagopal S, Moffat K (2003) The LOV domain family: photoresponsive signaling modules coupled to diverse output domains. Biochemistry 42:2-10

Fu G, Nagasato C, Ito T, Müller DG, Motomura T (2012) Ultrastructural analysis of flagellar development in plurilocular sporangia of Ectocarpus siliculosus (Phaeophyceae). Protoplasma 250:261-272

Fujita S, Iseki M, Yoshikawa S, Makino Y, Watanabe M, Motomura T, Kawai H, Murakami A (2005) Identification and characterization of a fluorescent flagellar protein from the brown alga Scytosiphon lomentaria (Scytosiphonales, Phaeophyceae): A flavoprotein homologous to Old Yellow Enzyme. Eur J Phycol 40:159-167

Geller A, Müller DG (1981) Analysis of the flagellar beat pattern of male Ectocarpus siliculosus gametes (Phaeophyta) in relation to chemotactic stimulation by female cells. J Exp Biol 92:53-66

Green JC, Leadbeater BSC, Diver WL (1989) The chromophyte algae: problems and perspectives. Oxford Science, Oxford, $\mathrm{p} 429$

Iseki M, Matsunaga S, Murakami A, Ohno K, Shiga K, Yoshida K, Sugai M, Takahashi T, Hori T, Watanabe M (2002) A blue-light-activated adenylyl cyclase mediates photoavoidance in Euglena gracilis. Nature (Lond) 415:1047-1051

Jahn TL, Landman MD, Fonseca JR (1964) The mechanism of locomotion of flagellates. II. Function of the mastigonemes of Ochromonas. J Protozool 11:291-296

Jekely G (2009) Evolution of phototaxis. Philos Trans R Soc Lond B Biol Sci 364:2795-2808

Kato Y, Kogame K, Nagasato C, Motomura T (2006) Inheritance of mitochondrial and chloroplast genomes in the isogamous brown alga Scytosiphon lomentaria (Phaeophyceae). Phycol Res 54:65-71

Kawai H (1988) A flavin-like autofluorescent substance in the posterior flagellum of golden and brown algae. J Phycol 24:114-117

Kawai H (1992) Green flagellar autofluorescence in brown algal swarmers and their phototactic responses. Bot Mag Tokyo 105:171-184

Kawai H, Inouye I (1989) Flagellar autofluorescence in forty-four chlorophyll c-containing algae. Phycologia 28:222-227

Kawai H, Müller DG, Fölster E, Häder DP (1990) Phototactic responses in the gametes of the brown alga, Ectocarpus siliculosus. Planta (Berl) 182:292-297

Kawai H, Kubota M, Kondo T, Watanabe M (1991) Action spectra for phototaxis in zoospores of the brown alga Pseudochorda gracilis. Mol Cell Biochem 161:17-22

Kimura K, Nagasato C, Kogame K, Motomura T (2010) Disappearance of male mitochondrial DNA after 4-celled stage sporophyte of the isogamous brown alga Scytosiphon lomentaria (Scytosiphonales, Phaeophyceae). J Phycol 46:143-152

Losi A, Gärtner W (2012) The evolution of flavin-binding photoreceptors: an ancient chromophore serving trendy blue-light sensors. Annu Rev Plant Biol 63:49-72

Maier I, Müller DG (1986) Sexual pheromones in algae. Biol Bull 170:145-175

Manton I (1959) Observations on the internal structure of the spermatozoid of Dictyota. J Exp Bot 10:448-461

Matsunaga S, Uchida H, Iseki M, Watanabe M, Murakami A (2010) Flagellar motions in phototactic steering in a brown algal swarmer. Photochem Photobiol 86:374-381

Motomura $T$ (1990) Ultrastructure of fertilization in Laminaria angustata (Phaeophyta, Laminariales) with emphasis on the behavior of centrioles, mitochondria and chloroplasts of the sperm. J Phycol 26:80-89

Motomura T, Nagasato C, Kimura K (2010) Cytoplasmic inheritance of organelles in brown algae. J Plant Res 123:185-192

Müller DG (1966) Untersuchungen zur Entwicklungsgeschichte der Braunalge Ectocarpus siliculosus aus Neapel. Planta (Berl) 98:57-68 
Müller DG (1967) Ein leicht flüchtiges Gyno-Gamon der Braunalge Ectocarpus siliculosus. Naturwissenshaften 54:496-497

Müller DG (1968) Versuche zur Charakterisierung eines Sexuallockstoffers bei Braunalge Ectocarpus siliculosus. I. Methoden, Isolierung und gaschromatographischer Nachweis. Planta (Berl) 81:160-168

Müller DG, Jaenicke L, Donike M, Akintobi T (1971) Sex attractant in a brown alga: chemical structure. Science 171:815-817

Müller DG, Maier I, Müller H (1987) Flagellum autofluorescence and photoaccumulation in heterokont algae. Photochem Photobiol 46:1003-1008

Nagasato C (2005) Behavior and function of paternally inherited centrioles in brown algal zygotes. J Plant Res 118:361-369

Nagasato C, Motomura T (2002) Influence of the centrosome in cytokinesis of brown algae: polyspermic zygotes of Scytosiphon lomentaria (Scytosiphonales, Phaeophyceae). J Cell Sci $115: 2541-2548$

Nagasato C, Motomura T (2004) Destruction of maternal centrioles during fertilization of the brown algae, Scytosiphon lomentaria (Scytosiphonales, Phaeophyceae). Cell Motil Cytoskeleton 59:109-118

Ntefidou M, Iseki M, Watanabe M, Lebert M, Häder D-P (2003) Photoactivated adenylyl cyclase controls phototaxis in the flagellate Euglena gracilis. Plant Physiol 133:1517-1521

O'Kelly CJ (1989) The evolutionary origin of the brown algae: information from studies of motile cell ultrastructure. In: Green JC, Leadbeater BSC, Diver WL (eds) The chromophyte algae: problems and perspectives. Oxford University Press, Oxford, pp 255-278

Peters AF, Scornet D, Müller DG, Kloareg B, Cock JM (2004) Inheritance of organelles in artificial hybrids of the isogamous multicelluar chromist alga Ectocarpus siliculosus (Phaeophyceae). Eur J Phycol 39:235-242

Schatten G (1994) The centrosome and its mode of inheritance: the reduction of the centrosome during gametogenesis and its restoration during fertilization. Dev Biol 165:229-335

Sineshchekov OA, Jung K-H, Spudich JL (2002) Two rhodopsins mediate phototaxis to low- and high-intensity light in Chlamydomonas reinhardtii. Proc Natl Acad Sci USA 97:8689-8694

Suetsugu N, Wada M (2013) Evolution of three LOV blue light receptor families in green plants and photosynthetic stramenopiles: phototropin, ZTL/FKF1/LKP2 and aureochrome. Plant Cell Physiol 54:8-23

Suzuki T, Yamasaki K, Fujita S, Oda K, Iseki M, Yoshida K, Watanabe M, Daiyasu H, Toh H, Asamizu E (2003) Archaeal-type rhodopsins in Chlamydomonas: model structure and intracellular localization. Biochem Biophys Res Commun 301:711-717

Togashi T, Cox PA (2004) Phototaxis and the evolution of isogamy and 'slight anisogamy' in marine green algae: insights from laboratory observations and numerical experiments. Bot J Linn Soc 144:321-327

Togashi T, Motomura T, Ichimura T, Cox PA (1999) Gametic behavior in a marine green alga, Monostroma angicava: an effect of phototaxis on mating efficiency. Sex Plant Reprod 12:158-163

van den Hoek C, Mann DG, Jahns HM (1995) Algae: an introduction to phycology. Cambridge University Press, Cambridge, p 623 